\title{
Risk Minimization of Hemolytic Disease of the Fetus and Newborn Using Droplet Digital PCR Method for Accurate Fetal Genotype Assessment of RHD, KEL, and RHCE from Cell-Free Fetal DNA of Maternal Plasma
}

\author{
Radek Vodicka ${ }^{1}$ (D) Jana Bohmova ${ }^{1, *}$, Iva Holuskova ${ }^{2}$, Eva Krejcirikova ${ }^{1}$, Martin Prochazka ${ }^{1}$ (D) and Radek Vrtel ${ }^{1}$ \\ 1 Department of Medical Genetics, University Hospital and Palacky University Olomouc, \\ 77520 Olomouc, Czech Republic; vodickar@fnol.cz (R.V.); eva.krejcirikova@fnol.cz (E.K.); \\ martin.prochazka@fnol.cz (M.P.); radek.vrtel@fnol.cz (R.V.) \\ 2 Department of Blood Transfusion, University Hospital and Palacky University Olomouc, \\ 77520 Olomouc, Czech Republic; iva.holuskova@fnol.cz \\ * Correspondence: Jana.Bohmova@fnol.cz; Tel.: +42-058-844-4636
}

Citation: Vodicka, R.; Bohmova, J.; Holuskova, I.; Krejcirikova, E.; Prochazka, M.; Vrtel, R. Risk Minimization of Hemolytic Disease of the Fetus and Newborn Using Droplet Digital PCR Method for Accurate Fetal Genotype Assessment of RHD, KEL, and RHCE from Cell-Free Fetal DNA of Maternal Plasma. Diagnostics 2021, 11, 803. https://doi.org/10.3390/ diagnostics11050803

Academic Editors: Antonio Farina and Paolo Ivo Cavoretto

Received: 13 April 2021

Accepted: 25 April 2021

Published: 28 April 2021

Publisher's Note: MDPI stays neutral with regard to jurisdictional claims in published maps and institutional affiliations.

Copyright: (c) 2021 by the authors. Licensee MDPI, Basel, Switzerland. This article is an open access article distributed under the terms and conditions of the Creative Commons Attribution (CC BY) license (https:// creativecommons.org/licenses/by/ $4.0 /)$.

\begin{abstract}
The molecular pathology of hemolytic disease of the fetus and newborn (HDFN) is determined by different $R H D, R H C E$, and KEL genotypes and by blood group incompatibility between the mother and fetus that is caused by erythrocyte antigen presence/absence on the cell surface. In the Czech Republic, clinically significant antierythrocyte alloantibodies include anti-D, anti-K, anti $\mathrm{C} / \mathrm{c}$, and anti-E. Deletion of the RHD gene and then three single nucleotide polymorphisms in the RHCE and KEL genes (rs676785, rs609320, and rs8176058) are the most common. The aim of this study is to develop effective and precise monitoring of fetal genotypes from maternal plasma of these polymorphisms using droplet digital (dd)PCR. Fifty-three plasma DNA samples (from 10 to 18 weeks of gestation) were analyzed (10 RHD, 33 RHCE, and $10 \mathrm{KEL}$ ). The ddPCR methodology was validated on the basis of the already elaborated and established method of minisequencing and real-time PCR and with newborn phenotype confirmation. The results of ddPCR were in $100 \%$ agreement with minisequencing and real-time PCR and also with newborn phenotype. ddPCR can fully replace the reliable but more time-consuming method of minisequencing and real-time PCR RHD examination. Accurate and rapid noninvasive fetal genotyping minimizes the possibility of HDFN developing.
\end{abstract}

Keywords: cell-free fetal DNA; hemolytic disease of fetus and newborn; RHD; RHCE; KEL; droplet digital PCR; noninvasive fetal genotyping; blood group incompatibility

\section{Introduction}

Hemolytic disease of the fetus and newborn (HDFN) is a disease that can cause perinatal morbidity and mortality [1-4]. Cellular and molecular pathogenesis of HDFN lies in maternal erythrocyte alloimmunization, which develops as a result of stimulation of the immune system by "foreign" antigens on the surface of fetal red blood cells. Maternal IgG alloantibodies are formed and cross the placenta, bind to fetal erythroid cells with unknown antigens, and then are destroyed in the reticuloendothelial system in the fetal spleen. Immune hemolysis can then cause varying degrees of fetal anemia. In the most severe cases, the fetus may die of heart failure in utero. In neonates, it can lead to severe forms of neonatal hyperbilirubinemia at risk of kernicterus [5-10]. Erythrocyte alloimmunization can be induced by blood transfusion containing a foreign erythrocyte antigen or during pregnancy as a result of feto-maternal hemorrhage, if the fetus has inherited an antigen from the father that is not present on the mother's erythrocytes. The first contact of the maternal immune system with an incompatible fetal erythrocyte antigen usually does not produce a severe form of HDFN. Antigen-incompatible fetuses are usually at risk of HDFN only in subsequent pregnancies [11-13]. Unlike alloantibodies directed against $\mathrm{Rh}$ 
antigens, anti-K antibodies cause suppression of erythropoiesis rather than hemolysis of incompatible erythrocytes. The $\mathrm{K}$ antigen is expressed by erythroid precursor cells, in contrast to $\mathrm{Rh}$ proteins, which are expressed on the surface of mature erythrocytes. In this case, the level of maternal anti-K antibodies is not a good indicator of HDFN and the severity of HDFN is difficult to predict because the correlation between alloantibody level and degree of fetal anemia is very small $[14,15]$.

RHD, RHCE, and KEL blood incompatibilities between the mother and fetus are among the most clinically serious in the Czech Republic in terms of possible development of HDFN. Clinically significant anti-erythrocyte alloantibodies include anti-D, anti-K/k, anti C/c, and anti-E/e. The presence or absence of an erythrocyte antigen on the cell surface is usually directly related to a particular genotype. In the European population, it is most often a complete deletion of the RHD gene and three single nucleotide polymorphisms (SNP) in the RHCE and KEL genes (rs676785, rs609320, and rs8176058).

Rh system antigens are encoded by two genes, RHD and RHCE. Both the genes are composed of 10 coding exons and have $94 \%$ sequence homology, which is evolutionarily conditioned by tandem duplication [16]. The most immunogenic and clinically important antigen of the Rh system is the D antigen [17]. The RHD negative genotype in the White population and thus the absence of the $\mathrm{D}$ antigen in the erythrocyte membrane is due to the deletion of the RHD gene in the homozygous state [16,18]. About 15-17\% of the White population has the RHD negative genotype [17].

The E/e antigen differs based on an SNP (rs609320, c.676G > C) in exon 5, which results in a Pro226Ala substitution in the fourth extracellular loop of the transmembrane protein [19]. The frequency of the E antigen in the White population reaches about $29 \%$; the frequency of the e antigen is $98 \%$ [20]. C/c antigens differ by six nucleotides, which encode four amino acid substitutions: Cys16Trp, He60Leu, Ser68Asn, and Ser103Pro. The C/c antigen specificity is determined by only one SNP (rs676785, c.307G > A), which results in a Ser103Pro substitution [19]. The frequency of the C antigen in the White population reaches about $68 \%$; the frequency of the c antigen is $80 \%$ [20].

In addition to alloimmunization in the Rh system, Kell alloimmunization is another common cause of hemolytic disease of the fetus and newborn in the White population. The KEL gene has two major codominant alleles: KEL1 and KEL2. The difference in the gene sequence between the KEL1 and KEL2 alleles is caused by a single nucleotide substitution in exon 6 (rs8176058, c.578C > T). The KEL1 allele is given by the presence of the T nucleotide and encodes the $\mathrm{K}$ antigen, the presence of the $\mathrm{C}$ nucleotide characterizes the KEL2 allele and encodes the $\mathrm{K}$ antigen [21,22]. The single nucleotide substitution $578 \mathrm{C}>\mathrm{T}$ results in the Thr193Met substitution [23,24]. The K antigen is present in $9 \%$ of the White population [25].

The aim of this work was to utilize the ddPCR method for noninvasive genotyping of the RHD allele, the KEL1 allele of the KEL gene, and the C or c and E alleles of the RHCE gene to design a reliable diagnostic strategy that is applicable to routine practice.

\section{Materials and Methods}

\subsection{Sample Collection}

Plasma samples and control plasma DNA for ddPCR assay specificity assessment were collected in collaboration with the Department of Medical Genetics, the Department of Obstetrics and Gynecology, and the Department of Transfusion Medicine of the University Hospital Olomouc. All of the subjects enrolled in the study signed an informed consent form approved by the Ethics Committee of the University Hospital Olomouc (approval code: $150 / 10)$. The samples that had already been tested by validated TaqMan real-time PCR and minisequencing methods [26-28] were used to validate and assess the ddPCR methodology. The correlation between fetal genotype and phenotype was further verified in the newborn using an immunoassay. The characterization of the tested plasma sample group for particular blood groups is in Table 1. Two positive and two negative control plasma DNA samples were used for each tested ddPCR assay. In these control samples, cffDNA genotypes were verified using DNA from neonatal buccal swabs. 
Table 1. Characterization of the sample group.

\begin{tabular}{|c|c|c|c|c|c|c|c|c|c|c|c|c|c|}
\hline \multirow{2}{*}{$\begin{array}{c}\text { Pregnant } \\
\text { Woman Blood } \\
\text { Antigen }\end{array}$} & \multirow{2}{*}{$n=53$} & \multirow{2}{*}{$\begin{array}{l}\text { Confirmation } \\
\text { Method }\end{array}$} & \multirow{2}{*}{$\begin{array}{l}\text { Newborn } \\
\text { Phenotype }\end{array}$} & \multirow{2}{*}{$\begin{array}{c}\text { Gestation } \\
\text { Week }\end{array}$} & \multicolumn{2}{|c|}{ Gestation Week } & \multirow{2}{*}{ Age } & \multicolumn{2}{|c|}{ Age } & \multirow{2}{*}{ BMI } & \multicolumn{2}{|c|}{ BMI } & \multirow{2}{*}{$\begin{array}{c}\text { Ethnic } \\
\text { Group of } \\
\text { Participants }\end{array}$} \\
\hline & & & & & Median & Mean & & Median & Mean & & Median & Mean & \\
\hline $\begin{array}{l}\text { "D-antigen" } \\
\text { negative } \\
\text { pregnant } \\
\text { women } \\
\text { (genotype } \\
\text { RHdd) }\end{array}$ & 10 & $\begin{array}{c}\text { Real-Time } \\
\text { PCR }\end{array}$ & $\begin{array}{l}5 \mathrm{RhD+} \\
5 \mathrm{RhD}-\end{array}$ & & & & & & & & & & \\
\hline $\begin{array}{l}\text { "C-antigen" } \\
\text { pregnant } \\
\text { women } \\
\text { (genotype } \\
\text { RHCC) }\end{array}$ & 11 & Minisequencing & $\begin{array}{l}4 \mathrm{RhC} \\
7 \mathrm{Rhc}\end{array}$ & & & & & & & & & & \\
\hline $\begin{array}{l}\text { "c-antigen" } \\
\text { pregnant } \\
\text { women } \\
\text { (genotype } \\
\text { RHcc) }\end{array}$ & 6 & Minisequencing & $\begin{array}{l}4 \mathrm{RhC} \\
2 \mathrm{Rhc}\end{array}$ & $10-18$ & 12 & 12.5 & $18-43$ & 29 & 30 & $17-36$ & 23 & 24.3 & Caucasian \\
\hline $\begin{array}{l}\text { "e-antigen" } \\
\text { pregnant } \\
\text { women } \\
\text { (genotype } \\
\text { RHee) }\end{array}$ & 16 & Minisequencing & $\begin{array}{l}12 \text { Rhe } \\
4 \mathrm{RhE}\end{array}$ & & & & & & & & & & \\
\hline $\begin{array}{l}\text { "k-antigen" } \\
\text { pregnant } \\
\text { women } \\
\text { (genotype } \\
\text { KEL2/KEL2) }\end{array}$ & 10 & Minisequencing & $\begin{array}{l}5 \text { Kell- } \\
5 \text { Kell+ }\end{array}$ & & & & & & & & & & \\
\hline
\end{tabular}

\subsection{Sample Preparation and DNA Isolation}

All 53 plasma samples and 8 control samples from pregnant subjects were collected into 9-mL tubes containing ethylenediaminetetraacetic acid (EDTA). Anticoagulated blood was placed on ice immediately after collection and was processed up to $4 \mathrm{~h}$ after sampling. Plasma was separated from the cellular fraction of blood using double centrifugation at $4{ }^{\circ} \mathrm{C}(1600 \times g$ for $10 \mathrm{~min}$ and $16,000 \times g$ for $10 \mathrm{~min})$. The plasma samples were frozen until further processing at $-80^{\circ} \mathrm{C}$. Plasma-cell-free (cf) DNA was isolated from $5 \mathrm{~mL}$ of plasma using the QIAamp Circulating Nucleic Acid Kit (Qiagen, Venlo, The Netherlands).

\subsection{Determination of Fetal Blood Genotype by ddPCR}

Two assays were designed for each tested blood group. The ddPCR assays tested for each genotype were designed to keep the length of the PCR products as short as possible. Specificity of primers and probes were optimized using control samples by two annealing temperatures. The sequence of $\beta$-globin was used as an internal control to amplify and quantify the ddPCR RHD assay. Conditions of testing and optimization of ddPCR assays are stated in Table 2. 
Table 2. Conditions of testing and optimization of ddPCR assays.

\begin{tabular}{|c|c|c|c|c|c|c|c|c|c|c|}
\hline \multirow{2}{*}{ Gene, SNP rs Number } & \multirow{2}{*}{ Allele } & \multirow{2}{*}{ Primer F $\left(5^{\prime}-3^{\prime}\right)$} & \multirow{2}{*}{ Primer R $\left(5^{\prime}-3^{\prime}\right)$} & \multicolumn{3}{|c|}{ Probe $\left(5^{\prime}-3^{\prime}\right)$} & \multirow{2}{*}{ PCR Product bp } & \multirow{2}{*}{ Specificity to cffDNA } & \multicolumn{2}{|c|}{ Optimal Annealing Temperature } \\
\hline & & & & Fluorophore & Sequence of the Probe & Quencher & & & $55^{\circ} \mathrm{C} * *$ & $60^{\circ} \mathrm{C}$ \\
\hline \multirow{2}{*}{ RHD } & \multirow{2}{*}{ RHD } & $\begin{array}{l}\text { GGGTGTTGTA } \\
\text { ACCGAGTGCTG }\end{array}$ & $\begin{array}{l}\text { CTCCAAGCAG } \\
\text { ACCCAGCAAG }\end{array}$ & \multirow{2}{*}{ 56-FAM } & \multirow{2}{*}{$\begin{array}{l}\text { CCCACAGCTCCAT } \\
\text { CATGGGCTACAA }\end{array}$} & \multirow{2}{*}{ 3IAkFQ } & 72 & ${ }^{*}$ YES & YES & YES \\
\hline & & $\begin{array}{l}\text { GGGTGTTGTA } \\
\text { ACCGAGTGCTG }\end{array}$ & $\begin{array}{l}\text { CCGGCTCC } \\
\text { GACGGTATC } \\
\end{array}$ & & & & 134 & YES & YES & YES \\
\hline$\beta$-globin & - & $\begin{array}{l}\text { GTGCATCTGAC } \\
\text { TCCTGAGGAGA }\end{array}$ & $\begin{array}{c}\text { CCTTGATACC } \\
\text { AACCTGCCCAG }\end{array}$ & 5HEX & $\begin{array}{c}\text { AAGGTGAACGTG } \\
\text { GATGAAGTTGGTGG }\end{array}$ & 3IAkFQ & 74 & ${ }^{*}$ YES & YES & YES \\
\hline \multirow{3}{*}{ RHCE, rs609320 } & RHE & $\begin{array}{l}\text { ATTCTTCCTT } \\
\text { TGGATTGGAC } \\
\end{array}$ & $\begin{array}{l}\text { CTTGTGGAT } \\
\text { GTTCTGGC }\end{array}$ & 5HEX & $\begin{array}{l}\text { TCAGCAGAG } \\
\text { GAGAGTTG }\end{array}$ & 3IAkFQ & 64 & ${ }^{*}$ YES & YES & YES \\
\hline & \multirow{2}{*}{ RHe } & $\begin{array}{c}\text { ATTCTTCCT } \\
\text { TTGGATTGGAC }\end{array}$ & $\begin{array}{l}\text { CTTGTGGA } \\
\text { TGTTCTGGC }\end{array}$ & \multirow{2}{*}{ 56-FAM } & \multirow{2}{*}{$\begin{array}{l}\text { TCAGCAGA } \\
\text { GCAGAGTTG }\end{array}$} & \multirow{2}{*}{ 3IAkFQ } & 64 & ${ }^{*}$ YES & YES & YES \\
\hline & & $\begin{array}{c}\text { TGGCATTCTT } \\
\text { CCTTTGGATTGG }\end{array}$ & $\begin{array}{c}\text { CTCAGACCTTTG } \\
\text { GAGCAGGAGT }\end{array}$ & & & & 134 & YES & YES & YES \\
\hline \multirow{3}{*}{ RHCE, rs676785 } & \multirow{2}{*}{ RHC } & $\begin{array}{l}\text { AATACCTGAA } \\
\text { CAGTGTGATG }\end{array}$ & $\begin{array}{l}\text { CTGCTGG } \\
\text { ACGGCTTC }\end{array}$ & \multirow{2}{*}{ 5HEX } & \multirow{2}{*}{$\begin{array}{l}\text { CCTTCCCA } \\
\text { GAAGGGAAC }\end{array}$} & \multirow{2}{*}{ 3IAkFQ } & 74 & ${ }^{*}$ YES & YES & NO \\
\hline & & $\begin{array}{l}\text { CCAGCCACCA } \\
\text { TCCCAATACC }\end{array}$ & $\begin{array}{l}\text { TGTGCAGTGG } \\
\text { GCAATCCTG }\end{array}$ & & & & 94 & YES & YES & NO \\
\hline & RHc & $\begin{array}{l}\text { CCAGCCACCA } \\
\text { TCCCAATACC }\end{array}$ & $\begin{array}{l}\text { TGTGCAGTGG } \\
\text { GCAATCCTG }\end{array}$ & 56-FAM & $\begin{array}{c}\text { GATGACCACCTT } \\
\text { CCCAGGAGGGAA }\end{array}$ & 3IAkFQ & 94 & YES & YES & NO \\
\hline \multirow{4}{*}{$K E L, \mathrm{rs} 8176058$} & \multirow{2}{*}{ KEL1 } & \multicolumn{2}{|c|}{$\begin{array}{l}\text { ddPCR Mutation Assay: KEL } \\
\text { p.T193M, Human }\end{array}$} & 56-FAM & $\begin{array}{l}\text { ddPCR Mutation } \\
\text { Assay: KEL } \\
\text { p.T193M, Human }\end{array}$ & 3IAkFQ & 65 & ${ }^{*}$ YES & YES & NO \\
\hline & & $\begin{array}{l}\text { GGTAAATGGA } \\
\text { CTTCCTTAAAC }\end{array}$ & $\begin{array}{l}\text { CTGAAGAAA } \\
\text { GGGAAATGG }\end{array}$ & 56-FAM & $\begin{array}{l}\text { TAACCGAATGCTGAG } \\
\text { ACTTCTGATGAGTCAG }\end{array}$ & 3IAkFQ & 77 & NO & NO & NO \\
\hline & \multirow{2}{*}{ KEL2 } & $\begin{array}{r}\text { ddPCR Mutc } \\
\text { p.T193 }\end{array}$ & $\begin{array}{l}\text { n Assay: KEL } \\
\text { Human }\end{array}$ & 5HEX & $\begin{array}{l}\text { ddPCR Mutation } \\
\text { Assay: KEL } \\
\text { p.T193M, Human }\end{array}$ & 3IAkFQ & 65 & ${ }^{*}$ YES & YES & NO \\
\hline & & $\begin{array}{l}\text { GGTAAATGGA } \\
\text { CTTCCTTAAAC }\end{array}$ & $\begin{array}{l}\text { CTGAAGAAAG } \\
\text { GGAAATGG }\end{array}$ & 5HEX & $\begin{array}{l}\text { TAACCGAACGCTGAG } \\
\text { ACTTCTGATGAGTCAG }\end{array}$ & 3IAkFQ & 77 & NO & NO & NO \\
\hline
\end{tabular}

* Assays selected for ddPCR as proper for plasma samples analysis. ${ }^{* *}$ Annealing temperature $55^{\circ} \mathrm{C}$ was used for plasma samples analysis, as optimal. 
The reactions mix for DNA isolated from the plasma were prepared in a $22-\mu \mathrm{L}$ volume. Premix contained $11 \mu \mathrm{L}$ of $2 \times$ ddPCR Supermix for Probes (no dUTP) (Bio Rad, Hercules, CA, USA), $1.1 \mu \mathrm{L} 20 \times$ target primers/probe (FAM) in the final concentration of primer $9 \mathrm{pmol} / \mathrm{L}^{-1}$ and probe $2.5 \mathrm{pmol} / \mathrm{L}^{-1}$ ) (Integrated DNA Technologies, Inc. (IDT),Coralville, Iowa, USA), $1.1 \mu \mathrm{L} 20 \times$ target primers/probe (HEX) in the final concentration of primer $9 \mathrm{pmol} / \mathrm{L}^{-1}$ and probe $2.5 \mathrm{pmol} / \mathrm{L}^{-1}$ ) (IDT), and $8.8 \mu \mathrm{L}$ plasma DNA or PCR water (TopBio, Prague, Czech Republic) as NTC. Reaction mix for commercial ddPCR mutation assay:KEL p.T193M, human was prepared in a $22 \mu \mathrm{L}$ volume. Premix contained $11 \mu \mathrm{L}$ of $2 x$ ddPCR supermix for probes (no dUTP) (Bio Rad), $1.1 \mu \mathrm{L}$ assay (FAM + HEX), $1.1 \mu \mathrm{L}$ PCR water, and $8.8 \mu \mathrm{L}$ plasma DNA or PCR water (Top-Bio) as NTC. The droplets were generated from reaction mixes and droplet generation oil for probes (Bio Rad) in the QX200 Automated Droplet Generator in a final volume of $40 \mu \mathrm{L}$. After droplet generation, thermal cycling proceeded in the C100 Touch Thermal Cycler (Bio Rad). Amplification was performed by ramp rate $2{ }^{\circ} \mathrm{C} / \mathrm{s}$ under the following conditions: $95^{\circ} \mathrm{C} 10 \mathrm{~min}, 40 \mathrm{PCR}$ cycles with $94{ }^{\circ} \mathrm{C} 30 \mathrm{~s}, 55^{\circ} \mathrm{C}$, or $60{ }^{\circ} \mathrm{C} 60 \mathrm{~s}$ profile, $98^{\circ} \mathrm{C} 10 \mathrm{~min}$. After thermal cycling, samples were placed in the QX200 Droplet Reader (Bio Rad). The QuantaSoft Software version 1.7.4 (Bio Rad) was used for assay analysis and evaluation.

\section{Results}

Basic ddPCR parameters and cell-free plasma DNA (cffDNA) genotype results are shown in Table 3. All the results were in $100 \%$ agreement with the minisequencing and real-time PCR and with the newborn phenotype.

Table 3. Results of RHD, RHCE, and KEL genotyping from maternal cffDNA and basic ddPCR parameters.

\begin{tabular}{|c|c|c|c|c|c|}
\hline Maternal Genotype $(n)$ & $\begin{array}{l}\text { Fetal Genotype } \\
* / \text { Phenotype } * *(n)\end{array}$ & $\begin{array}{c}\text { FAM (Blue) } \\
\text { Channel Positive } \\
\text { Droplets Mean } \\
\text { (Min; Max) }\end{array}$ & $\begin{array}{c}\text { VIC (Green) } \\
\text { Channel Positive } \\
\text { Droplets Mean } \\
\text { (Min; Max) }\end{array}$ & $\begin{array}{l}\text { Negative Droplets } \\
\text { Mean (Min; Max) }\end{array}$ & $\begin{array}{l}\text { Fetal Fraction } \\
\text { Percentage Mean } \\
\text { (Min; Max) }\end{array}$ \\
\hline \multirow[t]{2}{*}{ RHD- (10) } & RHD+/RhD+ (5) & $47.6(28 ; 91)$ & $1540(467 ; 2875)$ & $13,761(11,583 ; 16,561)$ & $9 \%(5.6 \% ; 25 \%)$ \\
\hline & RHD-/RhD- (5) & $0.6(0 ; 2)$ & $1457(562 ; 2767)$ & $14,240(10,471 ; 17,560)$ & \\
\hline \multirow[t]{2}{*}{ RHee (16) } & RHee (12)/Rhee(12) & $792(295 ; 1809)$ & $0.4(0 ; 1)$ & $11,735(10,417 ; 13,687)$ & \\
\hline & RhEe (4)/RhEe (4) & $1450(289 ; 2854)$ & $25.6(8 ; 49)$ & $12,479(9096 ; 14,939)$ & $7 \%(3.5 \% ; 11 \%)$ \\
\hline \multirow[t]{2}{*}{ RHCC (11) } & $R H C c(4) / \mathrm{RhCc}(4)$ & $21(18 ; 26)$ & $672(522 ; 805)$ & $13,706(11,718 ; 17,142)$ & $8 \%(6.6-10 \%)$ \\
\hline & RHCC (7)/RhCC (7) & $1(0 ; 3)$ & $938(239 ; 2474)$ & $12,669(10,528 ; 13,717)$ & \\
\hline \multirow[t]{2}{*}{ RHcc (6) } & $R H C c(2) / R h C c(2)$ & 379 and 517 & 44 and 54 & & $26 \%$ and $23 \%$ \\
\hline & RHcc (4)/Rhcc(4) & $695(390 ; 1284)$ & $1.4(0 ; 5)$ & & \\
\hline \multirow[t]{2}{*}{ KEL2 (10) } & KEL1 (5)/K (5) & $22(17 ; 31)$ & $760(376 ; 1341)$ & $14,237(13,558 ; 15,069)$ & $7 \%(5.5 \% ; 11 \%)$ \\
\hline & KEL2 (5)/k (5) & & $625(440 ; 922)$ & $14,328(13,598 ; 15,321)$ & \\
\hline NTC (23) & NTC (23) & $0.55(0 ; 3)$ & $0.22(0 ; 4)$ & $15,646(12,448 ; 17,735)$ & \\
\hline
\end{tabular}

* Confirmed by minisequencing and by real-time PCR; ** confirmed by newborn phenotype immunotest; ${ }^{* * *}$ fetal fraction (cffDNA fraction) was calculated with the assumption that maternal genotype is in homozygous status and that the droplets, if positive, contain only one specific DNA molecule. CffDNA fraction calculation formula: number of the only fetus specific positives (FSP) divided by ((the number of maternal specific positives (MSP) minus FSP) divided by 2)); NTC-non-template control.

\section{Discussion}

The incompatibility of the RhD system is considered to be the most clinically significant. Most laboratories that provide noninvasive cffDNA RHD genotyping perform a real-time PCR test for the presence or deletion of the RHD gene. Our previous study confirmed that for the Czech population RhD negativity is almost exclusively associated with the deletion of the entire RHD gene [26].

Other variants associated with blood incompatibility may also have clinical impacts in the Czech and/or in Central European population, especially RHCE and KEL genes. For 
RHCE and KEL, it is necessary to distinguish an SNP between the homozygous mother and heterozygous fetus.

RHD tests using real-time PCR and RHCE and KEL using minisequencing have already been introduced at our workplace [26-28]. One of the aims of the study was to methodically unify both procedures and, in the case of RHCE and KEL, to simplify and speed up the examination.

To optimize the ddPCR assays, primers and probes were designed (Table 2) to meet the following criteria: the primer and probe sequence specificity (neither the primers nor the probes should interfere in other than desired polymorphic sites), GC percentage, similar primer and probe Tm, and the length of the PCR product (ideally below $100 \mathrm{bp}$ ).

The assays that showed minimum (ideally zero) non-specific positive droplets and the assays with the shortest PCR products were selected for the subsequent validation and confirmation study.

The basic characteristics of ddPCR were assessed for individual assays and the percentage of fetal fraction was estimated (Table 3, Figure 1). The total number of droplets ranged from 11,000 to 18,000 . The vast majority were negative. For total plasma DNA, the number of positive droplets ranged from 376 to 2875 . When only the fetal DNA fraction were assessed, the number of positive droplets ranged from 8 to 91.

Due to the low percentage of positive droplets, the calculation of the amount of fetal fraction was based on the assumption that one DNA molecule occupies one droplet. Another assumption is that the maternal genotype is in a homozygous status and if the fetal genotype is different from the maternal one, it must therefore be in a heterozygous status.

The percentage of fetal fraction is very variable from $3.5 \%$ to $26 \%$, which corresponds to other studies [29-33]. We did not find any correlation when assessing the total and fetal fraction.

Comparison of real-time PCR and ddPCR methodology in noninvasive RHD fetal genotyping:

ddPCR accuracy according to our results is comparable with real-time PCR; this is in agreement with the study by Svobodova et al., 2015 [34]. Sillence et al., 2015 demonstrated, on the basis of the sequence from the SRY gene, higher sensitivity of ddPCR with comparison to real-time PCR [35].

Analysis duration and economic aspects are very similar. In addition, by ddPCR it is possible to absolutely quantify the amount of cffDNA.

Comparison of minisequencing with ddPCR methodology:

Noninvasive genotyping of SNPs using real-time PCR may be limited due to the non-specific fluorescent background [27]. To avoid the real-time PCR limitation, the minisequencing methodology was optimized and validated. The minisequencing method is able to determine fetus specific SNP if the amount of cffDNA fraction is as low as 1\% [27]. Compared to ddPCR, the minisequencing methodology is more laborious. Briefly, after the 1st PCR, purification follows, and the next step is the minisequencing PCR, followed by further purification and separation by capillary electrophoresis. Due to the many steps and procedures, the whole test takes 2 days to complete; ddPCR can be performed in half a working day. Based on our study, the accuracy test is comparable; moreover, similarly to RHD genotyping, the amount of cffDNA can be exactly measured and quantify.

Due to the very "clean" NTC histogram profile, it is possible to empirically set the limit of the maximal number of false positive droplets to 4 [36]. The base of our study resulted in the minimal limit of fetal fraction positive droplets that can be estimated to the limit value of 5 . The total amount of cffDNA according to the ddPCR results of samples with different genotypes was sufficiently robust so the probability of false negative results was minimized. Nevertheless, the analysis with the result around the minimal positive droplet limit should always be repeated. 

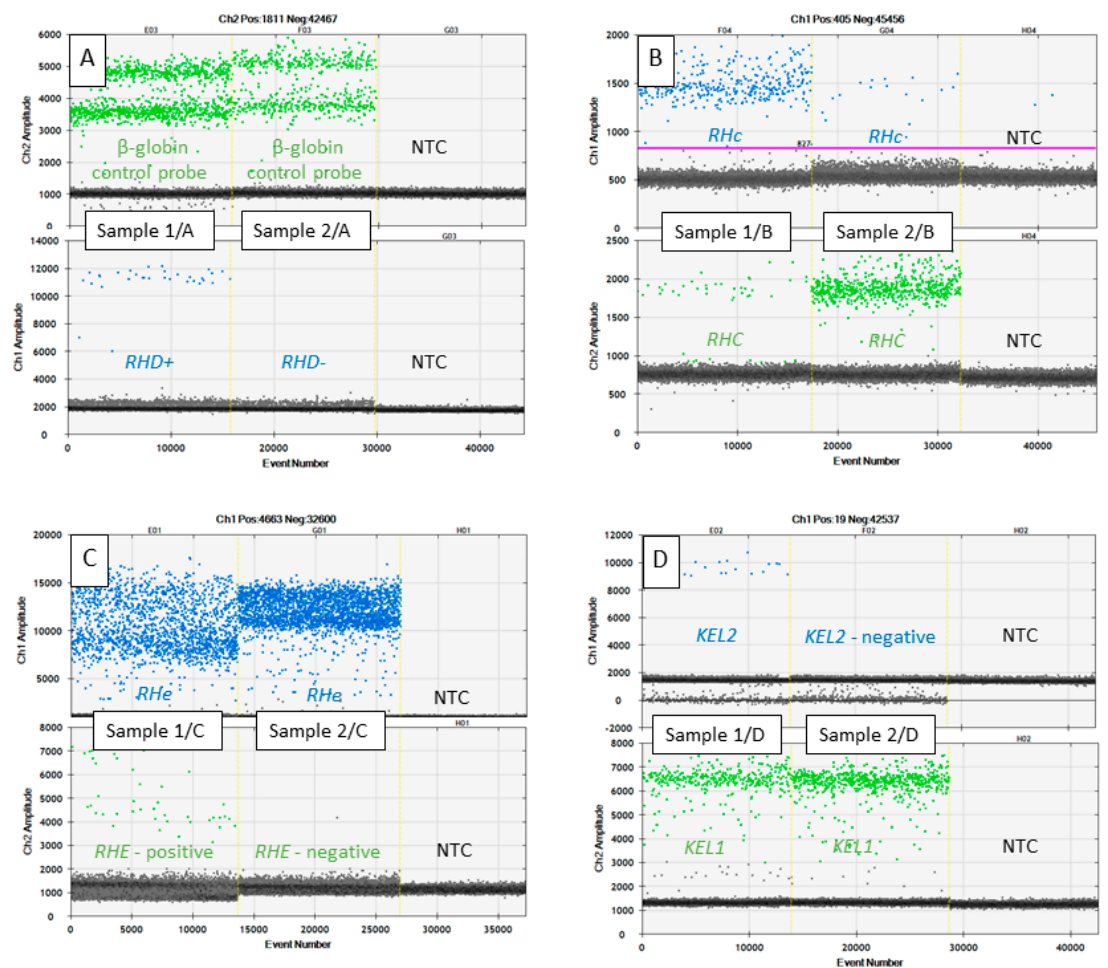

Figure 1. Graphical outputs from one dimensional graph between the fluorescence intensity ( $y$ axis) and droplet number ( $x$-axis) of RHD, RHCE, and KEL genotyping from maternal cell-free plasma DNA; (A) green channel indicates plasma DNA control $\beta$-globin amplification, blue channel indicates $R H D$ exon 7 positive droplets originate from the fetus. Maternal genotype in Sample 1/A is $R H D-/ R H D$ - while the fetal genotype is $R H D+/ R H D-$, maternal genotype is $R H D-/ R H D-$ and the fetal genotype is also $R H D-/ R H D$ - in Sample 2/A; (B) blue channel positive droplets indicate variant $R H c$ and green channel indicates $R H C$ variants, maternal genotype in Sample 1/B is $R H c c$ while fetal genotype is $R H C c$, maternal genotype is RHCC and fetal genotype is RHCc in Sample 2/B. In the case of RHc measurements, the QuantaSoft software was not able to set the cut-off line so it had to be done manually. Therefore, the purple cutoff line is visible; (C) green channel positive droplets indicate variant $R H E$, blue channel positive droplets indicate variant $R H e$. Plasma DNA sample 1/C contains both the maternal RHee genotype and different RHEe fetal genotype. The same genotypes RHee (maternal and fetal) are shown in the sample 2/C; (D) blue channel positive droplets indicate KEL1 variant, green channel positive droplets indicate KEL2 variant. Plasma DNA sample 1/D contains both the maternal KEL2/KEL2 genotype and different KEL1/KEL2 fetal genotype. Sample 2/D illustrates the same KEL2/KEL2 genotypes. NTC: Non-template control.

Few studies have been performed regarding the similar genotype spectrum of RHD, $K E L$, and RHCE blood incompatibility. Finning et al. (2007) successfully tested the real-time PCR method to test the same variant spectrum as in our study [37]. Cro et al. (2016) described noninvasive Real-time PCR KEL genotyping by incorporating allele-specific probes [38]. O'Brien et al. (2020) published a study that describes ddPCR utilization for noninvasive testing of fetal variants associated with Kell, RhCE, and Duffy antigens [39].

The NGS (next generation sequencing) methodology can also be used to accurately determine fetal blood group genotyping [40].

ddPCR is widely used for noninvasive prenatal detection of various types of mutations in many genetic diseases such as monogenic hereditary diabetes mellitus [41] and mutations in the NF1 [42] and CFTR genes [42,43].

The Czech population spectrum of investigated polymorphisms that may lead to HDFN was set on the basis of a wide discussion of leading experts in the Czech Republic addressing the monitoring of pregnancies at risk of HDFN. 
The open ddPCR platform offers very flexible potential extensions with additional blood incompatibility assays if required.

\section{Conclusions}

ddPCR is a generally useful tool for detecting cffDNA from maternal plasma. We adapted the method for the genotyping and assessment of fetal genetic variants that are responsible for the clinically most significant antierythrocyte alloantibodies, anti-D, anti-K, anti C/c, and anti-E, and may result in HDFN development. The method can fully replace the reliable but time-consuming method of minisequencing, and RHD examination using real-time PCR can be replaced by ddPCR. Accurate and rapid fetal genotyping of $R H D$, RHCE, and KEL minimizes the risk of HDFN developing.

Author Contributions: Study design, R.V. (Radek Vodikca) and J.B., ddPCR assay design, R.V. (Radek Vodikca) and J.B.; plasma collection, E.K.; clinical data collection, R.V. (Radek Vrtel), I.H. and M.P. All authors have read and agreed to the published version of the manuscript.

Funding: This research was funded by a grant from the Ministry of Health of the Czech Republic: conceptual development of research organization MH CZ-DRO (FNOL, 00098892) 2020.

Institutional Review Board Statement: The study was conducted according to the guidelines of the Declaration of Helsinki, and approved by the by the Ethics Committee of the University Hospital Olomouc (approval code: 150/10; approved on 20 September 2010).

Informed Consent Statement: Informed consent was obtained from all subjects involved in the study.

Conflicts of Interest: All the authors declare no conflict of interest.

\begin{tabular}{|c|c|}
\hline$\beta$-globin & hemoglobin subunit beta \\
\hline cfDNA & cell free deoxyribonucleic acid \\
\hline cffDNA & cell free fetal deoxyribonucleic acid \\
\hline $\begin{array}{l}\text { CFTR } \\
\text { ddPCR }\end{array}$ & $\begin{array}{l}\text { cystic fibrosis transmembrane conductance regulator } \\
\text { droplet digital polymerase chain reaction }\end{array}$ \\
\hline DNA & deoxyribonucleic acid \\
\hline dUTP & $2^{\prime}$-deoxyuridine, $5^{\prime}$-triphosphate \\
\hline EDTA & ethylenediaminetetraacetic acid \\
\hline FSP & fetus specific positives \\
\hline HDFN & Hemolytic disease of the fetus and newborn \\
\hline KEL & Kell metallo-endopeptidase \\
\hline MSP & maternal specific positives \\
\hline NF1 & neurofibromin 1 \\
\hline NGS & next generation sequencing \\
\hline NTC & non-template control \\
\hline PCR & polymerase chain reaction \\
\hline $\mathrm{Rh}$ & Rhesus \\
\hline RHCE & Rh blood group CcEe antigens \\
\hline RHD & Rh blood group D antigen \\
\hline SNP & single nucleotide polymorphisms \\
\hline SRY & sex-determining region \\
\hline $\operatorname{Tm}$ & melting temperature \\
\hline
\end{tabular}

\section{References}

1. Avent, N.D.; Reid, M. The Rh blood group system. Blood 2000, 95, 375-387. [CrossRef]

2. Bowman, J.M. RhD hemolytic disease of the newborn. N. Engl. J. Med. 1998, 339, 1775-1777. [CrossRef]

3. Eder, A. Update on HDFN: New information on long-standing controversies. Immunohematology 2006, 22, 188-195.

4. Urbaniak, S.; Greiss, S. RhD haemolytic disease of the fetus and the newborn. Blood Rev. 2000, 14, 44-61. [CrossRef] [PubMed]

5. Klein, H.G.; Anstee, D.J. (Eds.) Hemolytic disease of the fetus and the newborn. In Mollison's Blood Transfusion in Clinical Medicine, 12th ed.; Blackwell Scientific: Hoboken, NJ, USA, 2014; pp. 499-549. 
6. de Haas, M.; Thurik, F.F.; Koelewijn, J.M.; van der Schoot, C.E. Haemolytic disease of the fetus and newborn. Vox Sang. 2015, 109, 99-113. [CrossRef] [PubMed]

7. Moise, K.J. Fetal anemia due to non-Rhesus-D red-cell alloimmunization. Semin. Fetal Neonatal Med. 2008, 13, 207-214. [CrossRef] [PubMed]

8. Quinley, E.D. Haemolytic disease of the newborn. In Immunohaematology: Principles and Practice; Lippincott: New York, NY, USA, 1993; pp. 277-308.

9. Moise, K.J. Hemolytic disease of the fetus and newborn. In Maternal-Fetal Medicine: Principles and Practice, 6th ed.; Greene, M.F., Creasy, R.K., Resnik, R., Iams, J.D., Lockwood, C.J., Moore, T.R., Eds.; Saunders: Philadelphia, PA, USA, 2008 ; pp. $477-503$.

10. Hendrickson, J.E.; Delaney, M. Hemolytic Disease of the Fetus and Newborn: Modern Practice and Future Investigations. Transfus. Med. Rev. 2016, 30, 159-164. [CrossRef]

11. Maheshwari, A.; Carlo, W.A. Hemolytic disease of the Newborn (erythroblastosis fetalis). In Nelson Textbook of Pediatrics, 19th ed.; Kliegman, R.M., Stanton, B.F., Schor, N.F., St Geme, J.W., III, Behrman, R.E., Eds.; Thomas Press India Ltd.: New Delhi, India, 2012; pp. 615-619.

12. Maitra, A. Disease of infancy and childhood. In Robbins and Cortan Pathologic Basis of Disease, 8th ed.; Kumar, V., Abbas, A.K., Fausto, N., Aster, J.C., Eds.; Elsevier Inc.: New Delhi, India, 2010; pp. 447-486.

13. Kennedy, M.S. Perinatal issues in transfusion practices. In Technical Manual, 17th ed.; Roback, J.D., Grossman, B.J., Harris, T., Hillyer, C.D., Eds.; AABB: Bethesda, MD, USA, 2011; pp. 631-645.

14. Stephen, J.; Cairns, L.S.; Pickford, W.J.; Vickers, M.A.; Urbaniak, S.J.; Barker, R.N. Identification, immunomodulatory activity, and immunogenicity of the major helper T-cell epitope on the K blood group antigen. Blood 2012, 119, 5563-5574. [CrossRef] [PubMed]

15. Daniels, G. Kell and Kx Blood Group Systems. In Human Blood Groups, 3rd ed.; Wiley-Blackwell: Oxford, UK, 2013 ; Chapter 7.

16. Wagner, F.F.; Flegel, W.A. RHD gene deletion occurred in the Rhesus box. Blood 2000, 95, 3662-3668. [CrossRef]

17. Daniels, G. Human Blood Groups, 2nd ed.; Blackwell Science: Oxford, UK, 2002; ISBN 978-1-405-14007-2.

18. Colin, Y.; Chérif-Zahar, B.; Le Van Kim, C.; Raynal, V.; Van Huffel, V.; Cartron, J.P. Genetic basis of the RhD-positive and $\mathrm{RhD}$-negative blood group polymorphism as determined by Southern analysis. Blood 1991, 78, 2747-2752. [CrossRef]

19. Mouro, I.; Colin, Y.; Chérif-Zahar, B.; Cartron, J.P.; Le Van Kim, C. Molecular genetic basis of the human Rhesus blood group system. Nat. Genet. 1993, 5, 62-65. [CrossRef] [PubMed]

20. Reid, M.E.; Lomas-Francis, C. The Blood Group Antigen Facts Book, 2nd ed.; Elsevier Academic Press: New York, NY, USA, 2004.

21. Reid, M.E.; Denomme, G.A. DNA-based methods in the immunohematology reference laboratory. Transfus. Apher. Sci. 2011, 44, 65-72. [CrossRef] [PubMed]

22. Arnoni, C.P.; Muniz, J.G.; de Paula, T.A.; Person, R.D.; Gazito, D.; Baleotti WJr Barreto, J.A.; Castilho, L.; Latini, F.R. An easy and efficient strategy for KEL genotyping in a multiethnic population. Rev. Bras. Hematol. Hemoter. 2013, 35, 99-102. [CrossRef]

23. Lee, S.; Wu, X.; Reid, M.; Zelinski, T.; Redman, C. Molecular basis of the Kell (K1) phenotype. Blood 1995, 85, 912-916. [CrossRef]

24. Poole, J.; Warke, N.; Hustinx, H.; Taleghani, B.M.; Martin, P.; Finning, K.; Crew, V.K.; Green, C.; Bromilow, I.; Daniels, G. A KEL gene encoding serine at position 193 of the Kell glycoprotein results in expression of KEL1 antigen. Transfusion 2006, 46, 1879-1885. [CrossRef] [PubMed]

25. Lee, S. Molecular basis of Kell blood group phenotypes. Vox Sang. 1997, 73, 1-11, Erratum in: Vox Sang. 1998, 74, 58. [CrossRef]

26. Bohmova, J.; Lubusky, M.; Holuskova, I.; Studnickova, M.; Kratochvilova, R.; Krejcirikova, E.; Durdova, V.; Kratochvilova, T.; Dusek, L.; Prochazka, M.; et al. Two Reliable Methodical Approaches for Non-Invasive RHD Genotyping of a Fetus from Maternal Plasma. Diagnostics 2020, 10, 564. [CrossRef]

27. Böhmova, J.; Vodicka, R.; Lubusky, M.; Holuskova, I.; Studnickova, M.; Kratochvilova, R.; Krejcirikova, E.; Janikova, M.; Durdová, V.; Dolezalová, T.; et al. Clinical Potential of Effective Noninvasive Exclusion of KEL1-Positive Fetuses in KEL1-Negative Pregnant Women. Fetal Diagn Ther. 2016, 40, 48-53. [CrossRef]

28. Durdova, V.; Bohmova, J.; Kratochvilova, T.; Vodicka, R.; Holuskova, I.; Langova, K.; Lubusky, M. The effectiveness of KEL and RHCE fetal genotype assessment in alloimmunized women by minisequencing. Ceska Gynekol. 2020, 85, $164-173$.

29. Barrett, A.N.; Xiong, L.; Tan, T.Z.; Advani, H.V.; Hua, R.; Laureano-Asibal, C.; Soong, R.; Biswas, A.; Nagarajan, N.; Choolani, M. Measurement of fetal fraction in cell-free DNA from maternal plasma using a panel of insertion/deletion polymorphisms. $P L O S$ ONE 2017, 12, e0186771. [CrossRef]

30. Schlütter, J.M.; Hatt, L.; Bach, C.; Kirkegaard, I.; Kølvraa, S.; Uldbjerg, N. The cell-free fetal DNA fraction in maternal blood decreases after physical activity. Prenat. Diagn. 2014, 34, 341-344. [CrossRef] [PubMed]

31. Wong, D.; Moturi, S.; Angkachatchai, V.; Mueller, R.; DeSantis, G.; van den Boom, D.; Ehrich, M. Optimizing blood collection, transport and storage conditions for cell free DNA increases access to prenatal testing. Clin. Biochem. 2013, 46, 1099-1104. [CrossRef]

32. Yang, W.C.; Zhu, L.; Qiu, Y.M.; Zhou, B.X.; Cheng, J.L.; Wei, C.L.; Chen, H.C.; Li, L.Y.; Fu, X.D.; Fu, J.J. Isolation and analysis of cell-free fetal DNA from maternal peripheral blood in Chinese women. Genet. Mol. Res. 2015, 14, 18078-18089. [CrossRef] [PubMed]

33. Vodicka, R.; Vrtel, R.; Dusek, L.; Prochazka, M.; Schneiderova, E.; Vrbicka, D.; Krejcirikova, E.; Dhaifalah, I.; Santava, A.; Santavy, J. Refined fluorescent STR quantification of cell-free fetal DNA during pregnancy in physiological and Down syndrome fetuses. Prenat. Diagn. 2008, 28, 425-433. [CrossRef] 
34. Svobodová, I.; Pazourková, E.; Hořínek, A.; Novotná, M.; Calda, P.; Korabečná, M. Performance of Droplet Digital PCR in Non-Invasive Fetal RHD Genotyping-Comparison with a Routine Real-Time PCR Based Approach. PLoS ONE 2015, 10, e0142572. [CrossRef]

35. Sillence, K.A.; Roberts, L.A.; Hollands, H.J.; Thompson, H.P.; Kiernan, M.; Madgett, T.E.; Welch, C.R.; Avent, N.D. Fetal Sex and RHD Genotyping with Digital PCR Demonstrates Greater Sensitivity than Real-time PCR. Clin. Chem. 2015, 61, 1399-1407. [CrossRef] [PubMed]

36. Ouzegdouh Mammasse, Y.; Chenet, C.; Drubay, D.; Martageix, C.; Cartron, J.P.; Vainchenker, W.; Petermann, R. A new efficient tool for non-invasive diagnosis of fetomaternal platelet antigen incompatibility. Br. J. Haematol. 2020, 190, 787-798. [CrossRef]

37. Finning, K.; Martin, P.; Summers, J.; Daniels, G. Fetal genotyping for the K (Kell) and Rh C, c, and E blood groups on cell-free fetal DNA in maternal plasma. Transfusion 2007, 47, 2126-2133. [CrossRef]

38. Cro', F.; Lapucci, C.; Vicari, E.; Salsi, G.; Rizzo, N.; Farina, A. An innovative test for non-invasive Kell genotyping on circulating fetal DNA by means of the allelic discrimination of K1 and K2 antigens. Am. J. Reprod. Immunol. 2016, 76, 499-503. [CrossRef]

39. O'Brien, H.; Hyland, C.; Schoeman, E.; Flower, R.; Daly, J.; Gardener, G. Non-invasive prenatal testing (NIPT) for fetal Kell, Duffy and Rh blood group antigen prediction in alloimmunised pregnant women: Power of droplet digital PCR. Br. J. Haematol. 2020, 189, e90-e94. [CrossRef]

40. Wienzek-Lischka, S.; Krautwurst, A.; Fröhner, V.; Hackstein, H.; Gattenlöhner, S.; Bräuninger, A.; Axt-Fliedner, R.; Degenhardt, J.; Deisting, C.; Santoso, S.; et al. Noninvasive fetal genotyping of human platelet antigen-1a using targeted massively parallel sequencing. Transfusion 2015, 55, 1538-1544. [CrossRef] [PubMed]

41. Caswell, R.C.; Snowsill, T.; Houghton, J.A.L.; Chakera, A.J.; Shepherd, M.H.; Laver, T.W.; Knight, B.A.; Wright, D.; Hattersley, A.T.; Ellard, S. Noninvasive Fetal Genotyping by Droplet Digital PCR to Identify Maternally Inherited Monogenic Diabetes Variants. Clin. Chem. 2020, 66, 958-965. [CrossRef] [PubMed]

42. Gruber, A.; Pacault, M.; El Khattabi, L.A.; Vaucouleur, N.; Orhant, L.; Bienvenu, T.; Girodon, E.; Vidaud, D.; Leturcq, F.; Costa, C.; et al. Non-invasive prenatal diagnosis of paternally inherited disorders from maternal plasma: Detection of NF1 and CFTR mutations using droplet digital PCR. Clin. Chem. Lab. Med. 2018, 56, 728-738. [CrossRef] [PubMed]

43. Debrand, E.; Lykoudi, A.; Bradshaw, E.; Allen, S.K. A Non-Invasive Droplet Digital PCR (ddPCR) Assay to Detect Paternal CFTR Mutations in the Cell-Free Fetal DNA (cffDNA) of Three Pregnancies at Risk of Cystic Fibrosis via Compound Heterozygosity. PLoS ONE 2015, 10, e0142729. [CrossRef] 